\title{
John Cuthbert Hedley, biskup otevřený evoluci*
}

Dominik Opatrný

John Cuthbert Hedley, O.S.B. (1837-1915) byl britský benediktin a biskup v Newportu. Do dějin se zapsal především svým podílem na obnově struktur britské katolické církve. Nepřehlédnutelná je i jeho literární činnost spojená s obrovským odborným rozhledem. Pro nejstručnější charakteristiku si můžeme půjčit slova z jednoho jeho článku z roku 1898: „Ten, který sleduje postup současné vědy filosofickým okem“. ${ }^{1}$

Jediný doposud vydaný Hedleyův životopis pochází od jeho sekretáře doma Anselma Wilsona a podobá se spíše hagiografii. ${ }^{2} \mathrm{~K}$ porozumění určitým epizodám v biskupově životě významně přispělo poslední dílo španělského teologa Mariana Artigase, které vyšlo pod názvem Negotiating Darwin. ${ }^{3}$ Několik drobných postřehů doplňuje dom Alban Hood, benediktin z Douaiského opatství v Berkshire v stručném článku „Bishop John Cuthbert Hedley a Century On“" ${ }^{4}$

Cílem naší studie není přidat další Hedleyův životopis. Článek patří do řady studií přibližujících postoje katolických intelektuálů, kteří na konci devatenáctého století projevovali otevřenost vůči darwinismu. Jak upozorňuje Ctirad Václav Pospíšil, magisterium té doby hájilo především „rozlišování kompetenčních polí přírodovědy na jedné straně a filosofie

* Studie byla připravena za finanční podpory Grantové agentury České republiky prostřednictvím grantu „Teologie stvoření - výzvy prrírodních věd a trinitologie“, č. 16-08021S.

1 John Hedley, „Physical Science and Faith,“ Dublin Review 123 (1898): 241-261, zde s. 257.

2 Srov. J. Anselm Wilson, The Life of Bishop Hedley, London: Burns Oates and Washbourne LTD., 1930; srov. Alban Hood, „Bishop John Cuthbert Hedley a Century On,“ English Benedictine History (2015): 1-12, zde s. 3.

3 Srov. Mariano Artigas - Thomas F. Glick - Rafael A. Martínez, Negotiating Darwin: The Vatican Confronts Evolution, 1877-1902, Baltimore, MD: Johns Hopkins University Press, 2006.

4 Srov. Hood, „Bishop John Cuthbert Hedley a Century On“. 
a teologie na straně druhé“ ${ }^{5}$ Nepřekvapí, že v mozaice katolických osobností hájících víru se bude britský biskup angažovat také tímto směrem.

Benediktinský mnich, a tím méně newportský biskup nepsal žádná přírodovědná pojednání. Hedley ale relativně vstřícně reagoval na spisy dvou katolických evolucionistů, britského biologa St. George Mivarta a amerického kněze Johna A. Zahma. Zařadil se tak mezi nejvýznamnější církevní představitele, kteří na konci 19. století projevili vůči evoluční teorii jistou otevřenost, avšak ve svých formulacích balancovali na ostří nože.

Naše interpretace pramenů potvrzuje tuto Hedleyovu váhavou otevřenost, kvůli níž na něj naléhal hlavní americký propagátor evoluce mezi katolíky Augustine Zahm, aby navštívil USA. Na druhou stranu ale v Hedleyových postojích nacházíme větší rezervovanost, než jakou připouští Artigas.

\section{BENEDIKTIN - ŠÉFREDAKTOR - BISKUP}

John Hedley se narodil 15. dubna 1837 v Morpeth, malém městečku v severovýchodní Anglii ležícím asi padesát kilometrů jižně od skotských hranic. Katolická víra snad měla v jeho rodině starou tradici, protože roku 1595 nacházíme v Morpeth jméno Henry Hedlie na seznamech rekusantů, tedy těch, kteří odmítli přestoupit k anglikánství. ${ }^{6}$ Hedley studoval na benediktinské koleji v Ampleforthu (asi $25 \mathrm{~km}$ severně od Yorku). Osudy tohoto kláštera se podobají údělu ostatních benediktinských klášterů v Anglii: řeholníci sem uprchli po francouzské revoluci z Dieulouard, kde od počátku sedmnáctého století udržovali tradici britského mnišství, na ostrovech zakázaného. ${ }^{7}$

$\mathrm{V}$ osmnácti letech vstoupil Hedley $\mathrm{k}$ benediktinům a přijal jméno Cuthbert po britském mnichu, opatovi a biskupovi ze sedmého století, který pocházel ze stejného kraje. O sedm let později, roku 1862 byl

5 Ctirad Václav Pospíšil, Zápolení o naději a lidskou diostojnost: Česká katolická teologie 1850-1950 a výzvy přírodních véd v širším světovém kontextu, Olomouc: VUP, 2014.

6 Srov. Michael CARTER, "Remembrance, Liturgy and Status in a Late Medieval English Cistercian Abbey: The Mourning Vestment of Abbot Robert Thornton of Jervaulx (1510-33)," Textile History 41, č. 2 (2010): 145-160, zde s. 156.

7 Srov. George Cyprian Alston, „Benedictine Order, The,“ in The Catholic Encyclopedia, sv. 2, New York: Robert Appleton Company, 1907, s. 443-465, zde 447. 
vysvěcen na kněze. Hned potom odešel učit na benediktinský institut v Belmont, Hereford, jihozápadně od Birminghamu. Věnoval se filosofii, teologii, patristice, církevním dějinám, mystice a zajímal se i o literaturu a př́rodní vědy. ${ }^{8}$ Celkem zde zůstal jedenáct let, než na svátek archanděla Michaela roku 1873 přijal plnost svátosti svěcení a ve svých třiceti šesti letech se stal pomocným biskupem $\mathrm{v}$ tehdejší diecézi Newport a Menevia v jižním Walesu.

Již během svých profesorských let Hedley př́ležitostně přispíval do časopisu Dublin Review. Toto katolické periodikum začalo vycházet roku 1836. Ačkoliv se svým jménem hlásilo k metropoli katolického Irska, vycházelo v Londýně a patřilo Westminsterskému arcibiskupství. ${ }^{9} \mathrm{~V}$ šedesátých letech silně propagovalo papežskou neomylnost a po definování tohoto dogmatu na Prvním vatikánském koncilu roku 1870 začalo útočit na teorie Milla, Baina a Huxleye. Roku 1878 se ale westminsterský arcibiskup Vaughan rozhodl svěřit periodikum právě biskupu Hedleyovi. ${ }^{10}$ Mimochodem, byl to právě ten arcibiskup Vaughan, který musel roku 1900 již jako kardinál řešit kontroverzi kolem George J. Mivarta. ${ }^{11}$

Hedley si zvolil za cíl mírnit napětí a jeho moto znělo „Pravda, kultura, smíření". ${ }^{12}$ Důsledně se vyhýbal stranictví, takže odmítl i článek svého předchůdce na pozici šéfredaktora, když napadal kardinála Newmana. $^{13}$

Roku 1880 zemřel sídlení biskup Thomas Joseph Brown a na začátku následujícího roku Hedley nastoupil na jeho místo. Vést časopis vydržel do konce roku 1884, pak rezignoval. ${ }^{14}$ I potom jej ale okolnosti několikrát donutily zaslat do redakce príspěvek.

Pokud jde o směřování britské církve, Hedley významněji zasáhl ve dvou oblastech. V šedesátých letech 19. století postupně přestávaly britské univerzity ověřovat vyznání svých studentů, až roku 1871 sněmovna lordů zrušila zákon zakazující přijímat na univerzity nean-

8 Srov. Pascal Scotri, Out of Due Time: Wilfrid Ward and the Dublin Review, Washington: The Catholic University of America Press, 2006, s. 44.

9 Srov. A. Hilliard Atreridge, „Periodical Literature, Catholic - England, “ in The Catholic Encyclopedia, sv. 11, New York: Robert Appleton Company, 1911, s. 673-675, zde 673.

10 Srov. Scotri, Out of Due Time, s. 27.

11 Srov. Dominik Opatrný, „,Katolický evolucionista St. George J. Mivart o původu lidského těla a duše," Studia theologica 19, č. 1 (2017): 127-141.

12 Sсотті, Out of Due Time, s. 45-46.

13 Srov. Wilson, The Life of Bishop Hedley, s. 198-199.

14 Srov. Sсотті, Out of Due Time, s. 47. 
glikány. To otevřelo studentům všech vyznání cestu k univerzitnímu vzdělávání. Katolíkům ale ve studiu na státních univerzitách bránily papežské zákazy a vedla se diskuse, zda mládež pustit na již zavedené univerzity, nebo vybudovat vlastní katolickou univerzitu. Biskup Hedley se spolu s kardinálem Newmanem zasazoval za první možnost a roku 1895 papež Lev XIII. skutečně zákaz zrušil. ${ }^{15}$ Vedle vysokého školství měl ale starost i o vzdělání všech katolíků a př́sně napomínal rodiče, aby posílali své děti do školy, neupírali jim předtím doma snídani a nenutili je doma pracovat. ${ }^{16}$

Na přelomu 19. a 20. století se také dokončovala podoba britské církevní struktury, obnovené roku 1850 bulou Universalis Ecclesiae papeže Pia IX. Hedley zasáhl jak do diskusí o uspořádání kongregace benediktinských klášterů, tak diecézí ve Walesu. Nebyl ale nakloněn snaze získat si Velšany dvojjazyčným klérem, protože velšští katolíci pocházeli především z Irska a Anglie. ${ }^{17} \mathrm{~V}$ tom byl zajedno s biskupem Francisem Vaughanem z Menevie, na rozdíl od Francisova strýce, kardinála Vaughana, a Francisova předchůdce, biskupa Mostyna. ${ }^{18}$

Po smrti kardinála Vaughana roku 1903 se Hedley objevil mezi kandidáty na westminsterského arcibiskupa, ale mluvilo proti němu, že „už byl prríliš starý (šedesát šest let) a nejistý“ a že panovaly obavy, zda je jeho akademická mysl schopná dost energicky řídit nejdưležitějš́ diecézi Anglie. ${ }^{19}$

Hedley tak zůstal na newportském stolci až do své smrti na sv. Martina 1915. Zemřel na srdeční selhání po pětačtyřicetiletém trápení s revmatem..$^{20}$

15 Srov. Judith F. Cнамг, William Bernard Ullathorne, 1806-1889: A Different Kind of Monk, Leominster: Gracewing, 2006, s. 505.

16 Srov. Eric G. Tenbus, English Catholics and the Education of the Poor, 1847-1902, London: Routledge, 2015, s. 45.

17 Srov. Wilson, The Life of Bishop Hedley, s. 130-131.

18 Srov. J. Wyn Evans - Jonathan M. Wooding (ed.), St David of Wales: Cult, Church and Nation, Woodbridge: Boydell Press, 2007, s. 289.

19 Srov. Kester Aspden, Fortress Church: The English Roman Catholic Bishops and Politics, 1903-63, Leominster: Gracewing Publishing, 2002, s. 23.

20 Srov. Wilson, The Life of Bishop Hedley, s. 365-376. 


\section{První reakce na evoluční teoriI}

Rok 1871 přinesl bohatou úrodu spisů o evoluci. Na prvním místě vyšel Darwinův spis The Descent of Man and Selection in Relation to Sex. ${ }^{21}$ Na něj zareagoval katolický evolucionista St. George Mivart svou polemikou pod př́značným názvem On the Genesis of Species. Z Darwinových tezí napadal především centrální pozici přírodního výběru v procesu evoluce. ${ }^{22}$ Dále vyšly sebrané eseje A. R. Wallace pod názvem Contributions to the Theory of Natural Selection..$^{23}$ Tuto trojici konečně můžeme doplnit poslední knihou, která se objevila o rok dříve: disertace francouzského filosofa Henriho Joly pojednávající o instinktu. ${ }^{24}$

Hedley si tyto spisy přečetl ještě jako profesor na benediktinském institutu v Belmontu a rozhodl se na ně okamžitě zareagovat. Napsal čtyřicetistránkovou studii do červencového čísla Dublin Review pod názvem „Evolution and Faith“. Text vyšel anonymně, a tak jej Artigas s Hedleyem nespojuje, i když jej zmiňuje jako jednu z reakcí na Mivarta a i když cituje Hedleyův dopis, v němž se $\mathrm{k}$ autorství textu hlásí. ${ }^{25}$ Je proto zajímavé sledovat, jak se Hedleyovy postoje vyvíjely již od sedmdesátých let.

\subsection{Evoluce a křestanství - reakce na Darwina}

Hedley začíná svůj článek ostrou kritikou Darwina. Používá prý tolik informací, že je těžké odpovědět na jeho spisy, protože „pokud by některý z faktů zůstal nezmíněn, jeho sofistika by si zdánlivě vždy našla skrýšs,

21 Srov. Charles Darwin, The Descent of Man and Selection in Relation to Sex, London: John Murray, 1871.

22 Srov. St. George Mivart, On the Genesis of Species, London: Macmillan, 1871.

23 Srov. A. R. Wallace, Contributions to the Theory of Natural Selection, New York: Macmillan, 1871.

24 Srov. Henri Joly, L'instinct, ses rapports avec la vie et avec l'intelligence: Essai de psychologie comparée, Paris: E. Thorin, 1870.

25 Srov. Artigas - Glick - Martínez, Negotiating Darwin, s. 242-243 (anonymní reakce na Mivarta) a s. 231 (Hedley se hlásí k „Evoluce a víra“). Jakákoliv záměna je ale vyloučena, protože šestnáct let po autorově smrti byl text přetištěn spolu s dalšími Hedleyovými články v knize Evoluce a víra s dalšími eseji. Srov. John Hedley, Evolution and Faith with Other Essays, London: Sheed \& Ward, 1931. Srov. také ScotтI, Out of Due Time, s. 16. 
do které by se ještě mohla schovat.“ Dále tvrdí, že „Darwin naznačuje mnohem víc, než dokazuje, nebo alespoň předstírá, že dokazuje," a že jeho duch je na „špatné straně.“ Snaží se zpochybnit jeho neotřesitelnou autoritu: „Muž, který napsal skvělou knihu, která byla úspěšná a hojně čtená, vždy získá větší reputaci, než zasluhuje. ${ }^{\text {"26 }} \mathrm{Na}$ druhou stranu ale na Darwinovi oceňuje, že pojednává o sexuálním výběru „způsobem, který [toto téma] zbavuje naprosto vší pohoršlivosti“ “. ${ }^{27}$

Na dalších stranách Hedley zmiňuje teologické obtíže, které evoluce vyvolává: materialisticky popírá rozlišení mezi hmotou a duchem a tím také dogma o zvláštním stvoření lidské duše. Dále „podle všeho odporuje přejatému mínění, že životní principy říše živočichů a rostlin byly také výsledkem zvláštních stvořitelských aktů a že těla prvních lidí byla zázračně utvořena Bohem“. ${ }^{28}$

Stejnou trojici výhrad najdeme v reakci na články Johna Augustina Zahma (viz kap. 3), kde bude Hedley hájit, že v prvním př́padě musel Bůh prímo zasáhnout do běhu světa a $\mathrm{v}$ dalších dvou prrípadech je to pravděpodobné.

Pak přichází na řadu Darwinovo tvrzení, že „dal smrtelný úder obecně zastávané doktríně, že každý druh byl stvořen zvlášt” “. ${ }^{29} \mathrm{Na}$ následujících stranách Hedley dopodrobna rozebírá patristické teorie o stvoření, zejména Augustina a Basila, potažmo Ambrože. ${ }^{30}$ Dochází k závěru:

[Z] tohoto shrnutí dvou hlavních škol patristické interpretace Geneze se zdá být dostatečně zřejmé, že s ohledem na všechny organismy nižší než člověk nezakazuje katolická víra nikomu zastávat názor, že život, at už rostlinný, nebo živočišný, byl na světě v zárodku během jeho stvoření, a potom se rozvinul řádnými procesy do všech možných druhů, které jsou dnes na zemi. ${ }^{\text {"31 }}$

Hned ale s obvyklou obezřetností dodává: „V žádném případě neř́káme, že je to pravdivé mínění." Možná tedy nedošlo k zázračnému stvoření - Hedley jej sice nepopírá, ale ani nepovažuje popírání za herezi. Takový názor byl tehdy téměř standardní pro evoluci v oblasti fauny a flory.

Hedley, Evolution and Faith, s. 1.

Hedley, Evolution and Faith, s. 3.

Hedley, Evolution and Faith, s. 4.

Hedley, Evolution and Faith, s. 7.

Srov. Hedley, Evolution and Faith, s. 9-15.

Hedley, Evolution and Faith, s. 15. 


\subsection{Evoluce člověka - reakce na Mivarta}

„Otázkou není okamžité stvoření člověka," tvrdí rezolutně Hedley. „Bez nejmenších pochyb se člověk stal člověkem ve chvíli, kdy do něj byla vdechnuta duchovní duše. “32 To znamená, že žádné tělo před vdechnutím lidské duše nemohlo být lidským, což ostatně v evoluční teorii zastával již francouzský dominikán Dalmace Leroy. ${ }^{33}$

Pokud jde o vznik těla, Hedley ř́ká, že přicházejí v úvahu dvě hypotézy:

Bud' byla duše vdechnuta do dřive existujícího antropomorfního živočicha, nebo bylo z preexistující hmoty zformováno zvláštní antropomorfní tělo a v tutéž chvíli bylo oživeno duší. ${ }^{34}$

Dále tuto otázku řeší na základě zjevení. Nejprve ukazuje, že Adam měl podle „univerzální tradice církevních otců" přijít na svět jako dospělý, který nikdy nebyl embryem ani dítětem. ${ }^{35}$

$\mathrm{Z}$ toho vyvozuje:

[P]okud je tomu tak, bylo by méně zázračné vytvořit mu tělo zvlášt’ a spojit dohromady duši a tělo v momentě vytvoření, než vzít dříve vyvinutého živočicha, vyhnat nebo nahradit animální duši a vdechnout do něj duši lidskou. ${ }^{36}$

Katoličtí zastánci evoluce, jako Augustine Zahm, ale z tohoto faktu dokazovali pravý opak: evoluční vznik lidského těla, který je mnohem komplexnější než okamžité stvoření, je větším znamením Boží moci a moudrosti. ${ }^{37}$

Hedley nicméně uzavírá:

Kloníme se k myšlence, že všechny tyto důvody ukazují, že je přinejmenším zbrklé a nebezpečné popírat, že Adamovo tělo bylo zformováno bezprostředně a téměř v jednom okamžiku ze země Bohem. ${ }^{38}$

\footnotetext{
32 Hedley, Evolution and Faith, s. 19.

33 Srov. Pospíšil, Zápolení, s. 180-181.

34 Hedley, Evolution and Faith, s. 19.

35 Srov. Hedley, Evolution and Faith, s. 21

36 Hedley, Evolution and Faith, s. 21.

37 Srov. John Augustine ZAHM, Evolution and Dogma, Chicago: D. H. McBride, 1896, s. 350.

38 Hedley, Evolution and Faith, s. 22
} 
Tím vlastně ř́íká, že Mivartova teze není herezí, ale že dostatečně nezdůvodňuje odklon od učení církevních otců a názoru teologů. Nejsou tedy zcela uzavřeny dveře ke změně doktríny. Není proto divu, že se další zastánci, např́íklad Zahm, snažili dokázat, že teze církevním otcům neodporuje. ${ }^{39}$

Podobně v souvislosti se stvořením Evy zdůrazňuje Hedley Suárezův názor, že biblický popis „ze žebra“ je potřeba číst doslova, protože se na doslovném čtení shodují všechny autority, s výjimkou kardinála Kajetána. ${ }^{40}$ I na tomto př́kladu je vidět, že Hedley jako správný akademik vždy poctivě zvažoval a uváděl všechny alternativní názory.

Hedley ale ví, že někteří z jeho čtenářù by mohli mít problém připustit existenci zázraků. Mohl se tedy člověk vyvinout $\mathrm{z}$ nižších živočichů se všemi svými schopnostmi? Pro Hedleye je to zásadní otázka lidské důstojnosti:

Budeme zastávat speciální stvoření a duchovnost duše, nebo pokračující evoluci a míchat intelekt $\mathrm{s}$ pocity ${ }^{41}$

Tím se dostává k široké otázce po vztahu mezi instinkty a intelektem, kterou na mnoha stranách vysvětluje na barvitém obraze válečné bitvy. Ve výkladu se inspiruje disertací Henriho Joly. ${ }^{42}$ Nakonec své závěry shrnuje:

Je heretické popírat oddělené a zvláštní stvoření lidské duše; a zpochybňovat, že Bůh bezprostředně a okamžitě (nebo téměř okamžitě) zformoval těla Adama a Evy - prvního z neživé látky a druhé z Adamova těla -, je přinejmenším zbrklé a možná také blízké herezi. ${ }^{43}$

Potom teprve jmenuje Mivarta, a to v pozitivním světle: oceňuje, že ukázal obtíže teorie přirozeného výběru. Zároveň ale dodává, že takováto vědecká odpověd’ nestačí, protože evolucionisté přidávají $\mathrm{k}$ faktům falešné metafyzické závěry. $Z$ univerzální platnosti nějakého zákona hic et nunc totiž vyvozují jeho univerzální platnost i v minulosti a budouc-

39 Srov. Dominik OpatrnÝ, ,John Augustine Zahm ve sporu o opičí původ člověka, “ Studia theologica 18, č. 4 (2016): 63-81.

40 Hedley, Evolution and Faith, s. 22.

41 Srov. Hedley, Evolution and Faith, s. 24.

42 Hedley, Evolution and Faith, s. 35, pozn. 24.

43 Srov. Hedley, Evolution and Faith, s. 38. 
nosti, což je ale možné jen za předpokladu, že chybí a priori jistota pro opak. Jejich závěry jsou proto nevědecké, a tedy mytologické. ${ }^{44}$

Na tomto místě přechází Hedley v masivní útok na protivníky po způsobu katolické apologetiky ve své nejtragičtější podobě:

\begin{abstract}
A at už se potom můžeme snažit o cokoliv dobrého a užitečného, nejprve je třeba jasně říct, že výmluvy našich odpůrců jsou neoprávněné, že jejich metoda je nelogická a že nic nemůže odporovat vědě víc než svalovat na ni odpovědnost za závěr, který nemůže pouhé pozorování faktů $\mathrm{v}$ žádném př́ípadě prokázat. ${ }^{45}$
\end{abstract}

Jak upozorňuje belfastský badatel Diarmid A. Finnegan, Hedley se k Mivartově knize Genesis of Species ještě znovu vrátil v anonymním textu v Dublin Review z ledna 1872. ${ }^{46}$ Ale musíme začít popořádku. Na Genezi druhů reagoval také Darwinův kolega Thomas Henry Huxley. Vysmál se Mivartovu výkladu Suáreze a jeho snaze smíŕit evoluci s křestanstvím: každý člověk si musí vybrat, „,ale at si nenamlouvá, že je nebo by mohl být jak věrným synem církve, tak loajálním vojákem vědy. ${ }^{447}$

Na tento text reagoval Hedley na šesti stranách. Razantně se postavil za Mivarta a nešetřil vůči němu chválou. Své teze znovu shrnul takto: Adamovo tělo mohlo vzniknout bud' evolucí, nebo okamžitým stvořením, přičemž pravděpodobnější je druhá varianta, „protože zahrnuje méně zázraků. “48 Pokud by Adam vznikl evolucí, pak se jako člověk nenarodil, ale duši dostal až během života, protože se člověk nemưže narodit ze zvířete. Pokud jde o Evu, Hedley připouští, že Písmo neříká přesně, jak byla stvořena, protože hebrejské ríb nemusí znamenat jen žebro, ale „domníváme se, že je potřeba se držet názoru, alespoň nyní, že Eva byla ,utvořena' okamžitým aktem Všemohoucího Boha, a to

44 Hedley, Evolution and Faith, s. 39.

45 Srov. Hedley, Evolution and Faith, s. 40.

46 Srov. Diarmid A. Finnegan, „Eve and Evolution: Christian Responses to the First Woman Question, 1860-1900," Journal of the History of Ideas 75, č. 2 (2014): 283-305, zde 300. Artigas tento text zmiňuje, ale neidentifikuje autora, srov. Artigas - Glick - Martínez, Negotiating Darwin, s. 243. Přitom na s. 198 Hedley odkazuje na svůj článek „Evoluce a víra".

47 Thomas Henry Huxley, „Mr. Darwin's Critics,“ Contemporary Review 18 (1871): 455458.

48 John C. Hedley, "The Contemporary Review for November 1871 and January 1872,“ Dublin Review 18 (1872): 195-200, zde s. 199. 
z určité části Adamova těla, která z něj byla vyňata. ${ }^{49}$ Diskuse se tedy komplikovala, když se přidala otázka původu první ženy.

Pokud jde o prvního muže, souhrnně lze říci, že Hedley na začátku sedmdesátých let nepovažoval Mivartovu tezi o vývoji lidského těla za heretickou, nýbrž za zbrklou a možná herezi blízkou. Tím ale nechal dveře otevřené pro další vývoj nauky. $V$ této kritice Mivarta nezmiňoval, jmenoval jej jen pozitivně. Ukazuje se tak, že Mivart byl i přes svoji odvážnou tezi stále brán jako fundovaný Darwinův odpưrce, což také vysvětluje, proč jeho spisy o evoluci nebyly udány u Kongregace pro index a proč jej papež vyznamenal doktorátem z filosofie.

\subsection{Polemika s Mivartem o kompetence vědních disciplín}

Další diskuse mezi Hedleyem a Mivartem na stránkách britských časopisů se odehrála v druhé polovině osmdesátých let. Artigas ji nepopisuje, protože se přímo netýká evoluce. Nicméně vhodně dokresluje metodologický rámec sporů i vývoj vztahů.

V letech 1885-1892 uveřejnil Mivart v časopise Nineteenth Century sérii sedmi článků, v nichž se snažil hájit církev před vědeckou komunitou, zároveň jí ale chtěl vytyčit směr, jímž se musí vydat, aby byla obhajitelná. Apologie tedy prezentuje některé církevní postoje jako překonané. Poslední tři články, pojednávající o možnosti zažívat štěstí v pekle, zařadila roku 1893 Kongregace pro index na seznam zakázaných spisů..$^{50}$ Newportský biskup ale Mivarta kritizoval již v osmdesátých letech.

Hedley se rozhodl reagovat na druhý Mivartův článek „The Catholic Church and Biblical Criticism“ uveřejněný roku 1887 ve filosofickém periodiku Nineteenth Century. ${ }^{51}$ Mivart se domníval, že konflikty mezi církví a biology jsou již zažehnány, zato správně usuzoval, že dějištěm dalších sporů bude biblická interpretace. ${ }^{52}$ Chtěl své čtenáře seznámit s nejnovějšími teoriemi kritické biblistiky, i když přiznával, že některé

49 Hedley, „The Contemporary Review," s. 200.

50 Srov. Artigas - Glick - Martínez, Negotiating Darwin, s. 248-249.

51 Srov. St. George Jackson Mivart, „The Catholic Church and Biblical Criticism,“ The Nineteenth Century 22 (1887): 31-51.

52 Srov. Mivart, „The Catholic Church and Biblical Criticism,“ s. 32. 
pozice „mohou být unáhlené, přehnané, nebo dokonce mylné“ ${ }^{53}$ Celkově však podle jeho mínění vyznívají přesvědčivě.

Hedley ve své odpovědi „Dr. Mivart on Faith and Science“ pro Dublin Review především hájil právo církve závazně interpretovat Písmo, zároveň však rozsáhle polemizoval s Mivartovou interpretací kauzy Galileo. ${ }^{54}$ Galileovi Mivart věnoval svou první studii a nyní jej zmiňuje jen okrajově. ${ }^{55}$ Nabízí se proto otázka, proč biskup reagoval až na druhý text. Odpověd' neleží ani tak v prezentovaných názorech jako spiše v tom, že o nich Mivart tvrdil, že mají tichou podporu církevních autorit: „,až doted’ jsem od žádné církevní autority neobdržel byt̉ jen osobní náznak nesouhlasu. ${ }^{156}$ Biskup tedy nechtěl připustit, aby mlčení představitelů bylo vykládáno jako souhlas.

Cílem Mivartovy argumentace je tvrzení, že evidentní omyl církevních autorit v kauze Galileo katolíkům štastně získal svobodu, která platí pro „veškerou vědu - geologii, biologii, sociologii, politickou ekonomii, historii a biblickou kritiku". ${ }^{\prime 7}$

Hedley nechce zpochybňovat ani potvrzovat Mivartovy názory na evoluci, ohrazuje se však proti jeho generalizujícím závěrưm o vztahu církevní autority a vědy:

Připustme pro účely argumentace, že dr. Mivart oprávněně požaduje ,svobodu' pro určitý typ evoluční teorie, pro ne-okamžité zformování těla prvního člověka a pro rozdělené autorství hexateuchu. Proč si neoddechne spokojen s prohlášením své svobody a nezdrží se formulování paušalizujícího principu, jako je ten, který jsme právě citovali? ${ }^{58}$

Sám Hedley hájí právo církve rozhodovat o těch otázkách vědy, at' už přírodní či historické, na něž se přímo váže Zjevení. Ve své reakci uvedl tři jasné př́íklady: zázračné početí Ježíše odmítané fyziology, reálnou př́tomnost v eucharistii popíranou chemiky a vzkříšení, jež má

53 Mivart, „The Catholic Church and Biblical Criticism," s. 42.

54 Srov. John Cuthbert Hedley, „Dr. Mivart on Faith and Science,“ Dublin Review 18 (1887): 401-419.

55 Srov. St. George Jackson Mivart, „,Modern Catholics and Scientific Freedom,“ The Nineteenth Century 18 (1885): 31-51.

56 Mivart, „The Catholic Church and Biblical Criticism," s. 31.

57 Mrvart, „The Catholic Church and Biblical Criticism,“ s. 42 - Mivart zde cituje svůj předchozí článek.

58 Hedley, „Dr. Mivart on Faith and Science," s. 404-405. 
odporovat „,zákonům př́rody“. ${ }^{59}$ Netvrdil, že by Mivart tyto pravdy popíral, ale jeho vyjádření považoval za unáhlené:

Co měl říct, a co by řekl, kdyby si všiml tragických důsledků nepromyšlených řečí na toto téma, je, že pokud se nějaká z těchto autorit vyjádří ve věcech vědy nebo interpretace, které nemaji vazbu na zjevení, pak to nezavazuje katolíky k souhlasu.

Učitelský úřad tedy může „nepřímo a implicitně definovat vědeckou pravdu". ${ }^{60}$

Dál Hedley ukazuje na př́ikladu rev. Jeremiah Murphyho, že opačná strana se vyjadřuje umírněněji:

[N]a tomto běžném významu (textu Písma) můžeme trvat, dokud evolucionisté neukáží, že existuje dostatečný důvod, abychom se od něj odklonili. To zatím neudělali, a v důsledku toho není potřeba opustit prima facie pohled Písma na stvoření člověka. ${ }^{61}$

Potom Hedley představuje své čtyři principy, podle kterých má katolický teolog přistupovat k otázkám biologie a biblické interpretace: Zaprvé, není možné opouštět univerzální či kvaziuniverzální souhlas bez velmi přísného posouzení opačné pozice. Zadruhé, není vhodné považovat něco za propojené s pravdami víry, pokud pro to nejsou pádné důkazy. Zatřetí, lidští př́ijemci Zjevení nemuseli všechno zcela pochopit, takže může být Boží pravda zaznamenána nepřesně. Začtvrté, je potřeba trvat na moci církve „definovat nepřímo pravdy vědy nebo historie, které jsou propojené se zjevením, a posuzovat, kdy jsou skutečně takto propojené" ${ }^{\prime 2}$

I to je ale podle Hedleyho málo, protože církev vždy zakazovala i takové nauky, které ohrožovaly úctu k Písmu. „Podle mého názoru může být celkem oprávněné," vyvozuje z toho Hedley, "když vynáší svůj zákaz, i když se v některých případech stane, že se bude vědecky mýlit." "63 Důležitější než věda je totiž úcta k Písmu, a tak je možné zakázat i to, co Písmu odporuje jen podle dobového porozumění. To nevylučuje veškerou diskuzi, protože se nejedná o herezi v pravém slova smyslu, ale měla by nastoupit diskuse „v soukromí, s patřičným

59 Srov. Hedley, „Dr. Mivart on Faith and Science," s. 403.

60 Hedley, „Dr. Mivart on Faith and Science,“ s. 404, zdůraznění původní.

61 Hedley, "Dr. Mivart on Faith and Science," s. 405, zdůraznění původní.

62 Hedley, "Dr. Mivart on Faith and Science," s. 405.

63 Hedley, „Dr. Mivart on Faith and Science," s. 407. 
respektem a obezřetností, aby nedošlo k pohoršení celého katolického stádce. ${ }^{\prime \prime 6} \mathrm{Z}$ toho vyvozuje, že Galileovo učení bylo jakousi „,konstitutivní“ herezí, „protože všechno, co implikuje, že se Písmo mýlí, je hereze svou implikací" ${ }^{65}$ Církev tedy nepopírala určité vědecké mínění samo o sobě, ale to, že by dokazovalo, že se Písmo mýlí.

Pokud jde o osobní rovinu, Hedley si dává pozor, aby svůj text začal i ukončil chválou na Mivarta a jeho př́nos britské katolické církvi. Uvnitř ho ale nijak nešetří, když tvrdí, že se tento „znamenitý expert v biologii (...) v posledních měsících pustil, jak nám sděluje, do biblické kritiky“. ${ }^{66}$ Později zase v satirické narážce na navržený „,hřích zbrklého souhlasu“ ironicky glosuje: „Katalog hříchů je už tak dost dlouhý, ale moralista dr. Mivart nám otvírá nové a hrozivé možnosti." ${ }^{\text {"7 }}$ Tato kritika není zcela oprávněná, protože sám Mivart doznává: „,exegeze není mým oborem,“ a v článku popisuje názory současných protestantských biblistů, aniž by si nárokoval oprávnění je hodnotit. ${ }^{68}$

Hedley také vycítil a ostře kritizoval Mivartovy obavy o to, co si o něm řeknou jeho vědečtí kolegové:

[N]avrhovat $\mathrm{v}$ časopiseckém článku, plném strachu z toho, co o vás řeknou agnostičtí vědci a ne bez napůl potlačené a napůl vyjádřené nevraživosti vůči některým ,církevním autoritám', rozvržení vědecké teologie a anticipaci možností církevních rozhodnutí v př́ipadech, které ještě nikdy nenastaly, není ani moudré, ani užitečné. ${ }^{9}$

Při vší kousavosti ale nelze Hedleymu upř́t krásný britský humor v závěru článku:

Nepopírám, že přinejmenším v Anglii my všichni (snad s výjimkou biologů) jsme více nakloněni jemnému zacházení s animálním stvořením, než byli naši předci. ${ }^{70}$

Mivart na kritiku zareagoval článkem, v němž znovu vysvětloval svou pozici jako naprosto ortodoxní. Tento text uveřejnila redakce $D u$ -

64 Hedley, „Dr. Mivart on Faith and Science," s. 407.

65 Hedley, "Dr. Mivart on Faith and Science," s. 408.

66 Hedley, "Dr. Mivart on Faith and Science," s. 401.

67 Hedley, "Dr. Mivart on Faith and Science," s. 413.

68 Srov. Mivart, „The Catholic Church and Biblical Criticism," s. 42.

69 Hedley, „Dr. Mivart on Faith and Science," s. 404.

70 Hedley, "Dr. Mivart on Faith and Science," s. 417. 
blin Review spolu se závěrečným slovem biskupa $\mathrm{v}$ této kauze, $\mathrm{v}$ němž zopakoval své stanovisko a přidal výzvu k pokoře:

Nyní bych už nechtěl udělat nic jiného, než připomenout dr. Mivartovi, že vztahy mezi vírou a vědou, nad nimiž si lámal hlavu i sv. Augustin, nemůže uspokojivě upravit žádný člověk, který se vyzná jen ve vědě. ${ }^{71}$

Tuto dvoustránkovou odpověd' končí stejně, jako začínal svůj předchozí článek: chválou na Mivarta a na dílo, které pro britské katolíky vykonal.

Na tomto střetu je zajímavá především Hedleyho koncepce poměru mezi vědou a vírou, která je o necelých osmdesát let starší než vyjádření koncilních otců v Gaudium et spes 36, že pozemské skutečnosti mají své vlastní zákonitosti, v jejichž poznávání požívá věda autonomie. ${ }^{72} Z$ de se koncilní otcové jasně přiblížili Mivartově pozici bez nadbytečných Hedleyových upřesnění. Ani koncil ale zcela nevyřešil otázku rozsahu této autonomie, jak je vidět z pokoncilních diskusí o autonomní etice. Nakonec základní myšlenka Hedleyho platí i dnes: vědecké teorie, které popírají východiska křestanství, například svobodnou vůli nebo lidskou zodpovědnost, jsou pro křest’ana nepřijatelné.

\section{Hedely ChVÁlí Zahma a distancuje SE Od NĚJ}

Na stránkách Dublin Review se Hedley k tématu evoluce vrátil znovu po deseti letech, tentokrát ještě pozitivněji. V roce 1898 napsal pod názvem „Physical Science and Faith" reakci na čtyři spisy Johna Augustina Zahma z posledních let: ${ }^{73}$ Evolution and Dogma (1896), ${ }^{74}$ Bible, Science,

71 John Cuthbert Hedley, „The bishop of Newport's Rejoinder, “ Dublin Review 19 (1888): 188-189.

72 K diskusi o autonomii pozemských skutečností srov. Miroslav KaraBA, „Vzájomný vztah vedy a viery v dokumentoch Druhého vatikánskeho koncilu," Studia theologica 7, č. 1 (2005): 69-77, zde s. 72-73.

73 Srov. Hedley, „Physical Science and Faith“. „Fyzickou vědou“ se v dobové terminologii rozumí prírodní vědy.

74 Srov. John Augustine Zанм, Evolution and Dogma, Chicago: D. H. McBride, 1896. 
and Faith (1895), ${ }^{75}$ "Evolution and Teleology“ (1896) ${ }^{76} \mathrm{a}$ "Science and the Church" (1896). ${ }^{77}$ Tentokrát se ale sám stal cílem útoků italského konzervativního listu La Civiltà Cattolica.

\subsection{Recenze Zahmových knih}

Hedley na začátku vysvětluje rozdíl mezi samotnou evoluční teorií a proticírkevními výpady jejích zastánců. Potom píše o recenzovaném autorovi:

Argumentovat tedy ve prospěch evoluční hypotézy a zároveň se distancovat od všech jejích podporovatelů, kteř́ jakýmkoliv způsobem odporují katolické víre, je úkol, který vyžaduje jak jasnou hlavu, tak velkou nezávislost v úsudku.

A přesně to nachází u „vynikajícího amerického katolického autora a přednášejícího" reverenda doktora Johna Augustina Zahma, jehož nasazení vítá "s velkým potěšením a nadějí" ${ }^{78} \mathrm{~V}$ samotném textu ale Zahma nijak nešetří, naopak na několika místech ukazuje jeho přehnaný entusiasmus, který nevidí existující problémy.

Hned první nenápadná výtka je terminologická:

Podle dr. Zahma tedy existuje dilema mezi evolucí a tím, co je vágně nazváno ,kreacionismus'. Je zbytečné říkat, že to $\mathrm{v}$ žádném případě neznamená pochybnosti o Bohu coby stvořiteli nebe a zemé. ${ }^{99}$

Hedley zde připomíná, že i katolický evolucionista věří ve stvoření, a tak by bylo lepší druhou pozici označit jako zvláštní stvoření všech druhů.

75 Srov. John Augustine ZAHM, Bible, Science, and Faith, Baltimore: John Murphy \& co., 1894.

76 Srov. John Augustine ZAHM, „Evolution and teleology,“ Popular Science Monthly 52 (1898): 815-824.

77 Srov. John Augustine ZAHM, "Science and the Church," in Catholic Science and Catholic Scientists, Philadelphia: Kilner \& co., 1893, s. 9-54.

78 Hedley, „Physical Science and Faith," s. 243-244, 259.

79 Hedley, "Physical Science and Faith,“ s. 245. 
O něco dál odmítá tři Zahmovy teze, které vyznívají, jako kdyby evolucionismus musel vést $\mathrm{k}$ teismu. ${ }^{80}$ Zaprvé, evoluce předpokládá podle Zahma stvoření. Jenže podle Hedleyho „nepředpokládá stvoření o nic víc než mysl nebo zodpovědnost". Evoluce tedy nemůže být nějakým novým důkazem Boží existence, jen se dá s tradičními důkazy spojit. Zadruhé, evoluce předpokládá určité zákony a hybatele, které do ní byly vloženy při stvoření. To ale platí jen pro křestanskou evoluci. Naproti tomu většina evolucionistů zastává jinou koncepci, která si bez prvotního hybatele vystačí. Zatřetí, „stvořitelské jednání a jeho vliv stále trvají (...) a pouze ony působily ve všech nespočetných fázích evolučního procesu od atomu $\mathrm{k}$ monádě, od monády $\mathrm{k}$ člověku“. Takto silné vyjádření by ovšem znamenalo, že prostředí a snaha přežít nemají vưbec žádný vliv. Proto se Hedley s obvyklou ironií ptá:

Nemíní doktor Zahm spíš to, že kdyby byla určitá věc uspořádána jinak nebo měla jiné tendence, vyvíjela by se jiným směrem, a tedy ,stvořitelské jednání a vliv' jinými slovy prrirozenost - ovlivňuje vývoj? ${ }^{81}$

Jako prríklad uvádí vlak jedoucí Derbyshirskou pahorkatinou, u nějž parní síla není jedinou účinnou příčinou jeho klikaté jízdy.

Poté zaznívají velice tvrdá slova:

Rozumní lidé, zdálo by se, by nepředstírali, že evoluční teorie dělá bud’ existenci stvořitele, nebo jeho trvalou aktivitu ve stvoření jistějš́í, než byla dříve. ${ }^{82}$

Zároveň se ale velmi vstř́ícně vyjadřuje o evoluci, která „,nakolik je založená na pozorovaných faktech a ne zmanipulovaná $\mathrm{v}$ ukvapených a bezdůvodných generalizacích, je naprosto slučitelná s křestanskou vírou" ve stvořitele a $\mathrm{v}$ jeho trvalou aktivitu. ${ }^{83}$

Hedley tedy po přečtení Zahmových spisů nesdílí Američanův entusiasmus, podle něhož evoluce podporovala víru $\mathrm{v}$ Boha stvořitele a v jeho působení v současném světě, ale „pouze“ považuje evoluci za slučitelnou $s$ touto vírou. Evoluce nemůže zabránit teistovi, aby věřil

80 Srov. Hedley, „Physical Science and Faith,“ s. 247; Zahm, Evolution and Dogma, s. $431-432$.

81 Hedley, "Physical Science and Faith,“ s. 248.

82 Hedley, "Physical Science and Faith," s. 248, zdůraznění původní.

83 Hedley, "Physical Science and Faith,“ s. 248. 
v Boží zásah přinejmenším ve třech okamžicích: při vdechnutí racionální duše, při vzniku animálního života a při zformování těla prvního člověka. Naprostá jistota je ale pouze $v$ prrípadě lidské duše, o evoluci lidského těla Hedley silně pochybuje, nevylučuje ji však absolutně. Zajímavé je, že předpokládá zvláštní Boží zásah jen při vzniku prvních živočichů. Proč ne rostlin? V aristotelismu mají rostliny jen duši vegetativní, zatímco živočichové duši animální. Hedley navíc znal hypotetická mínění, podle nichž by chemici mohli jednoho dne vyrobit umělou buňku. ${ }^{84}$

Diskusi o antagonismu uzavírá:

At’ už jsou tvrzení a generalizace nevěříćch filosofů jakékoliv, nic v teorii evoluce ani nic prokázaného fakty není skutečně v protikladu ke katolické viře ${ }^{85}$

Na Hedleyových poznámkách je ovšem vidět, jak mu občas dělalo potíže přejít od filosofického myšlení $\mathrm{k}$ myšlení prrírodovědnému. Např́klad se domníval, že Darwinův koncept přirozeného výběru implikuje plán (design) v př́rodě, protože někdo musí vybírat s určitým úmyslem. ${ }^{86}$ Jenže výběr šlechtitelů zde nahrazuje boj o přežití, který eliminuje jedince hưre přizpůsobené aktuálním podmínkám. Naopak Spencerova teze o přežití nejpřizpưsobivějších se sice důsledně vyhýbá teleologii, podle Hedleyho však nic nevysvětluje, protože zůstává otázkou, jak se nejpřizpůsobivější stal nejpřizpůsobivějším. Nebere v potaz drobné odchylky všemi směry, z nichž přirozený výběr vybírá ty „vhodné“.

V závěru Hedley shrnuje své pochvaly i výtky vưči Zahmovi:

Zdá se mi, že katolický student, který pečlivě studuje stránky dr. Zahma, nebude váhat zavrhnout všechen strach, že by přijetí organické evoluce bylo jakkoliv nebezpečné pro víru. ${ }^{87}$

Zároveň ale chladí Zahmovo nadšení:

Nestačí vyřknout silná slova o „svobodě a licenci“ a tvrdit v obecných termínech, že jsou „zjevená pravda a dogma kompatibilní s nejdokonalejší intelektuální svo-

84 Srov. Hedley, „Evolution and Faith," s. 16-17, pozn. §.

85 Hedley, „Physical Science and Faith," s. 253.

86 Srov. Hedley, „,Physical Science and Faith," s. 256.

87 Hedley, „Physical Science and Faith,“ s. 258. 
bodou.“ (...) Určitě není doslovně pravda, že „Katolíci (...) nebudou připouštět, že by je požadavky dogmatu jakkoliv omezovaly při provozování vědy." ${ }^{\text {"8 }}$

Jako další př́klad situace, kdy zjevené pravdy vylučují určité vědecké teorie, uvádí hypotézu polygenismu, tedy že lidské rasy mají různý původ. ${ }^{89}$ Takové teorie, odporující biblické a církevní nauce o jednotě lidského rodu, na konci devatenáctého století skutečně existovaly. Mivart připomínal např́íklad Vogtovu teorii, že lidé starého světa jsou potomci afrických a asijských opic, zatímco lidé nového světa se vyvinuli z opic amerických. ${ }^{90}$

\subsection{Informační válka s La Civiltà Cattolica}

Jiné katolické periodikum, vlastněné také Westminsterskou arcidiecézí, The Tablet, zveřejňovalo souhrny článků v Dublin Review. V takovémto shrnutí vyzněla „Physical Science and Faith“ jako naprosto nekritické prijetí evoluce:

Biskup z Newportu, když se zabývá podrobněji evoluční teorií, ukazuje, že nakolik je založena na pozorovaných faktech, a ne na manipulovaných a zbrklých nepodložených generalizacích, je naprosto slučitelná s křestanskou vírou..$^{91}$

Toto shrnutí bylo přeloženo do italštiny a vyšlo s krátkým úvodem a závěrem v listu La Rassegna. ${ }^{92}$

Tím se diskuse dostala do Itálie a na Hedleyho mohl promptně zaútočit konzervativní list La Civiltà Cattolica, a to ještě v roce 1898. Reakce se ujal Salvatore Brandi, který nejprve správně upozornil na to, že italský článek zamlčuje, že podle biskupa Hedleyho vyžadoval vznik lidského těla také př́mý Boží zásah. ${ }^{93}$

V závěru svého textu ale Brandi zveřejnil, že Leroy musel své názory odvolat, což vrhlo negativní světlo na další duchovní, kteří z něj

88 Hedley, „Physical Science and Faith,“ s. 258.

89 Srov. Hedley, „Physical Science and Faith," s. 258, který odkazuje na ZAHM, Bible, Science and Faith, s. 40.

90 Srov. Mivart, On the Genesis of Species, s. 14.

91 „The Dublin Review," The Tablet, 29. 10. 1898, s. 590.

92 Srov. Artigas - Glick - Martínez, Negotiating Darwin, s. 227.

93 Srov. tamtéž, s. 228. 
vycházeli: na Zahma, biskupa Bonomelliho a nepřímo také na Hedleye. Podstatnějš́i než samotné odvolání je fakt, že se to stalo na základě „přezkoumání kompetentní autoritou v Římě“ ${ }^{94}$ První autorita, která čtenáře mohla napadnout, byla Kongregace sv. officia, nebở předně ta mohla rozhodovat $\mathrm{v}$ doktrinálních otázkách. Brandiho tvrzení mělo navíc punc potvrzené informace, protože La Civiltà Cattolica procházela vatikánským schválením.

Na tento text Hedley rychle zareagoval $\mathrm{v}$ časopise The Tablet $\mathrm{v}$ čísle z ledna 1899. Mivartův životopisec Jacob W. Gruber tento text chápal jako odvolání, zatímco Artigas zdůrazňuje podmíněnost biskupova tvrzení. ${ }^{95} \mathrm{~A}$ skutečně, poslední věta dopisu redakci zní:

At’ už je to jakkoliv, nemusím říkat, že pokud „kompetentní autorita“ rozhodla ve smyslu, v němž se zdá, že rozhodla, pak mínění, že Adamovo tělo se "vyvinulo“, musí být stále označováno jako „unáhlené“ - a ještě něco navíc. ${ }^{96}$

Nicméně předcházející slova ukazují, že i sám biskup byl přesvědčen, že legitimní autorita opravdu zasáhla:

„Autorita“, o níž se zde mluví, musí být, předpokládám, svaté Officium. „Mivartovu“ teorii proto není možné zastávat.

Kondicionál tedy neznačí podmínku, ale reálnou situaci, z níž vyplývá nepodmíněný závěr. Proto se biskup hájí a zdůrazňuje, že tuto teorii sám nijak nezastával, ale naopak ji už před třiceti lety označil za "unáhlenou“.

O tom, že se Hedley domníval, že Zahmovu knihu skutečně odsoudila Kongregace sv. officia, nacházíme důkaz v jeho korespondenci. V březnu 1901 napsal svému spolubratrovi v biskupské službě Peterovi Austinu O'Nellovi, že jej nedávno Zahm navštívil a zval přednášet do Spojených států. Přitom se svěřil se svými rozpaky:

94 Artigas - Glick - Martínez, Negotiating Darwin, s. 230.

95 Srov. Jacob W. Gruber, A Conscience in Conflict: The Life of St. George Jackson Mivart, New York: Columbia University Press, 1960, s. 188; Artigas - Glick - Martínez, Negotiating Darwin, s. 231-232.

96 J. C. Hedley, „,To the Editor of the Tablet,“ The Tablet 93, 14. 1. 1899, s. 59. 
Nevím, zda bych měl vyrazit pod patronátem dr. Zahma. Nejen že byl odsouzen Svatým Officiem (i když odsouzení nebylo zveřejněné), ale nemám valné mínění ani o jeho vkusu. ${ }^{97}$

Ovšem později získal Hedley více informací a zjistil, že domněnka ohledně zásahu Kongregace sv. officia byla falešná. Napsal o tom krátké vyjádření svému př́teli a připojil svolení se zveřejněním. Text vyšel roku 1902 v knize England and the Holy See: An Essay Towards Reunion. Hedley stručně popsal průběh událostí, přičemž své zřeknutí se Zahma prezentoval v kondicionálu. „Mezitím jsem se dozvěděl,“ Hedley uzavírá, „že zmíněné odsouzení, pokud vůbec zaznělo, vyšlo od dominikánského představeného, a vůbec ne od Svatého stolce ${ }^{\text {“ }} .^{98}$ Tato informace nebyla přsesná, protože knihy týkající se evoluce zakázala Kongregace pro index. Ta ovšem neměla možnost stanovit nějakou nauku, pouze bez dalšího upřesnění zakazovala texty, které by mohly být pro věřící nebezpečné. Dominikánský představený, Andreas Frühwirth, figuroval v kauze Dalmace Leroy, a to tak, že tlumočil závěry této kongregace svému podřízenému a vyžádal od něj odvolání..$^{99}$

Reakce La Civiltà Cattolica na sebe nenechala dlouho čekat. Salvatore Brandi cítil povinnost krátce reagovat, protože se tento dopis dostal do "několika katolických i nekatolických časopisů starého i nového světa." Pro svou repliku, která vyšla v březnu 1902, si vybral př́značný název „Evoluzione e domma: Erronee informazioni di un inglese“. ${ }^{100} \mathrm{~V}$ ní zopakoval své tvrzení, že kompetentní autority v Římě odsoudily evoluční vznik lidského těla, ale nechtěly zasáhnout veřejně, aby nevyvolaly rozruch. Touto autoritou měla být Kongregace sv. officia, takže se jedná o "autoritu nejvyššího tribunálu Svatého stolce“. ${ }^{101}$ Hedley už ale nepovažoval za nutné dál reagovat a tím polemika skončila.

97 Dopis citován v Hood, „Bishop John Cuthbert Hedley a Century On,“ s. 11.

98 Spencer John Jones, England and the Holy See: An Essay Towards Reunion, New York: Longmans Green \& co., 1902, s. 299.

99 Srov. Artigas - Glick - Martínez, Negotiating Darwin, s. 100-101.

100 Srov. Salvatore M. BRANDI, „Evoluzione e domma: Erronee informazioni di un inglese, " La Civiltà Cattolica 18, č. 6 (1902): 75-77.

101 Brandi, „Evoluzione e domma," s. 76. 
Hedley na rozdíl od Mivarta či Zahma nepsal o vztahu víry a vědy proto, že by potřeboval podělit se se čtenáři o výsledky svého bádání. Reagoval na dobovou diskusi a snažil se vyvažovat a stmelovat různé názorové proudy v církvi. Ukazoval jistou otevřenost vůči evoluci, ba dokonce i na rovině antropologie, ale upozorňoval na teologické problémy, které přináší.

Jeho postoje bychom mohli charakterizovat třemi slovy: loajalita - respekt - ráznost. Jakožto církevní představitel si dával vždy pozor, aby zůstal loajální vůči Římu. Nadšeně sledoval pokroky ve vědě a vůči vědcům projevoval respekt. Jakmile však dospěl k názoru, že je potřeba pokárat, byl velmi rázný. Snad i díky tomu si získal přezdívku „Smrtící Hedley“, anglicky „Deadly Hedley“. ${ }^{102}$ Přes veškerou svou snahu působit rozhodně ale máme doklady i o jeho vnitřní nejistotě. To ilustruje situaci tehdejší hierarchie, která se snažila postupovat rozhodně, ale vlastně nevěděla, co si s evolucí počít.

Ve vztahu k Mivartovi nikdy nechyběl prvek úcty a chvály. Dokud se držel biologie, byl chloubou britské katolické církve, jíž navíc sloužil jako protiváha k Darwinovi. Jakmile ale vstoupil na pole teologie či církevní politiky, neváhal ho Hedley razantně, a místy až sarkasticky odkázat do patřičných mezí.

V kontaktu s Zahmem se zase ukazovalo, jakým stigmatem bylo v tehdejší církvi dostat se na index. Ve své bezprostřední reakci na Evolution and Dogma dokázal Hedley Zahma jak pochválit, tak krotit jeho entusiasmus. Když se ale dozvěděl, že zmíněné dílo bylo zařazeno na seznam zakázaných knih, byt๋ dekret nebyl zveřejněn, začal pochybovat, zda má s Zahmem spolupracovat.

Na Hedleyho postojích můžeme vidět celou komplexnost dobového sporu. Nejednalo se jen o přípustnost evoluce. Šlo také o její využívání či spíše zneužívání ateisty v boji s náboženstvími. Potvrzuje se tolerance $\mathrm{v}$ oblasti evoluce fauny a flory i to, že otevřenost $\mathrm{v}$ této věci je $\mathrm{v}$ zásadě standardem. Třecí pole spočívalo v oblasti evolučního vzniku lidského těla, tedy hypotézy, která $v$ té době ještě nebyla dostatečně vědecky dokázaná (např̀. pozice Rudolfa Virchowa). Problém tedy není ve zdrženlivém postoji k evoluci, ale v paternalistickém prrístupu. Pokud Hedley

102 Srov. Hood, „Bishop John Cuthbert Hedley a Century On,“ s. 2. 
hájil právo církve zakazovat nauku, která by mohla odvádět lidi od víry, i kdyby byla pravdivá, musíme si uvědomit, že to dělal v době, která méně přála autonomii než doba dnešní. ${ }^{103}$ Nejen církev, ale celá společnost ještě musela ujít dlouhou cestu $\mathrm{k}$ překonání paternalismu.

\section{John Cuthbert Hedley, a Bishop Open to Evolution}

Keywords: Hedley, John Cuthbert (1837-1915); Evolution; Creation; Darwin, Charles (1809_ 1882); Mivart, St. George Jackson (1827-1900); Zahm, John Augustine (1851-1921)

Abstract: The article presents the constructive approach of John Cuthbert Hedley, bishop of Newport, towards the theory of evolution. It helps us understand the complex discussion in the Catholic Church at the end of the nineteenth century. In reactions to St. George J. Mivart, Hedley manifested great respect towards the famous biologist, but criticized him when entering the field of theology. In contact with John Augustine Zahm, Hedley was initially very supportive, though softening Zahm's enthusiasm. He later became more reserved and uncertain in his contacts because Zahm's book was placed on the index of prohibited books.

Mgr. Dominik Opatrný, Th.D. Katedra systematické teologie CMTF UP

Univerzitní 22

77111 Olomouc

dominik.opatrny@upol.cz

103 I dnes by si měl ale vědec klást otázku, zda zveřejněním výsledků svého výzkumu někoho nespravedlivě nepoškodí. Např́klad při výzkumu sexuálního jednání určitých skupin obyvatelstva je na místě otázka, zda data nebudou dezinterpretována a použita proti této skupině. 